\title{
Multicultural Education vs. Implicit and Explicit Ethnocentric Education: Text Analysis of a Contemporary Israeli Value Education Program
}

Roni ReINGOLD ${ }^{* 1}$ AND SARA ZAMIR ${ }^{2}$

$\propto$ In the year 2000, Israel purportedly adopted a multicultural educational policy. It replaced the covert assimilation policy, which was referred to as 'the integration policy'. The aim of the present study was to analyse the contemporary Israeli program of value education. Using the method of content analysis, the present study sought to determine whether the syllabi of the contemporary program reflect the adoption of a multicultural educational policy, or whether they produce only multicultural rhetoric. The findings reveal that the program reflected mainly the pluralistic approach while still maintaining traces of ethnocentric rhetoric of certain syllabi in the program.

Keywords: assimilation, educational policy, Israel, multiculturalism, value education 


\section{Multikulturna edukacija: implicitna in eksplicitna etnocentrična edukacija - vsebinska analiza sodobnega izraelskega programa za vzgojo za vrednote}

Roni ReIngold In SARA Zamir

$\propto \quad$ Leta 2000 je Izrael domnevno sprejel multikulturno edukacijsko politiko. Ta je nadomestila prikrito asimilacijsko politiko, ki je bila poimenovana kot integracijska politik«. Namen te raziskave je bil analizirati sodobni izraelski program za edukacijo vrednot. $\mathrm{Z}$ uporabo metod vsebinske analize je raziskava skušala ugotoviti, ali kurikulum sodobnega programa odraža sprejetje multikulturne edukacijske politike ali samo proizvaja multikulturno retoriko. Ugotovitve kažejo, da program predvsem odraža pluralistični pristop, medtem ko se še vedno ohranjajo sledi etnocentrične retorike $\mathrm{v}$ določenih delih kurikuluma.

Ključne besede: asimilacija, edukacijske politike, Izrael, multikulturalizem, edukacija vrednot 


\section{Introduction}

Since the establishment of the State of Israel in 1948, its Ministry of Education has had complete and centralised control, including in determining the educational policy and activities pertaining to all the schools in the country (Baratz \& Reingold, 2010), with exception of the Jewish ultra-Orthodox independent education. The ministry controls the schools' curricula; the matriculation examination; the teachers' preparatory education, accreditation procedures, and teachers' continuing professional development (Baratz, Reingold, \& Abuatzira, 2011). Subsequently, throughout the years of the existence of the State of Israel, this control has enabled the ministry to encourage conformist behaviour among teachers (Reingold, Baratz, \& Abuatzira, 2013).

Article B of a law dating from 1953, the 'Israel National Education Act', determined that the national education must be based on:

- the cultural values of Israel and its scientific achievements; love of country and loyalty to the State and the people of Israel; training in the fields of agriculture and industry; a pioneering spirit; and the aspiration to create a society built on freedom, equality, tolerance, mutual help, and love of humanity' (Kizel, 2005, p. 3).

- $\quad$ 'Cultural values of Israel [...] love of country and loyalty to the State' are all phrases that demonstrate the dominant social and educational policy that characterized the first decades after the State of Israel was founded: its goal was the 'integration of Diasporas (exiles)', to create a social 'melting-pot'.

Underlying this explicit assimilation policy was the wish to attract the Jewish immigrants from Islamic countries away from the cultures of their communities of origin and integrate them into the framework of what was considered the native Israeli culture. That is, the hegemonic and dominant one, a variation of the culture of the ethnic group which was referred as the elite- the veteran Ashkenazim ${ }^{3}$ (Sever, 2001; Yonah, 2005).

The melting pot policy (ideology) was replaced at the end of the $1960 \mathrm{~s}$ by a new policy, which was referred to as 'the integration policy' or 'the policy of cultural pluralism. This policy accepted the existence of a variety of cultural groups in one political/social entity and 'even' viewed it as normal (Gaynor, 2011; Lamme, 1996). However, the acceptance of the existence of various and different cultures and different culture groups in the national education framework does not necessarily mean that this policy reflects the State's vision, or that

3 'Ashkenazi' is the term used to refer to the Jews who came from eastern European countries and established the State. 
the State wishes to continue to foster this policy. It only means that the State allows it (Feinberg, 1996).

To put into practice the policy of integration, an organisational reform was carried out in the educational system. Before the reform, the educational system was composed of two segments: elementary school (Grade 1-Grade 8) and high school (Grade 9-Grade 12). Middle high school (Grade 7-Grade 9) was developed between these two segments. The organisational reform was followed by educational and ideological ones. Middle high school became the first educational arena accepting students from Ashkenazi and Mizrachi (Sephardic) 4 origin (previously, studies were segregated by area residents and consequently by ethnicity); nevertheless, no new programs were introduced featuring the culture and history of immigrants of Mizrachi origin (Yonah, 2005). In effect, the goal of the encounter between cultures (or ethnicities) was, as reflected in the words of the former education minister Zvulun Hamer, to 'ensure amicability between the population groups, foster a sense of belonging to society in general, and strengthen Israel's sense of unity' (Yonah, 2005, p. 68).

In contrast to the former description, in the last decade and a half, a new message can be heard from the Ministry of Education. The beginning of the shift was in the year 2000, when an amendment to the Israel National Education Act of 1953 was introduced. Specifically, the goals of national education in Israel were updated as well as the vision of the optimal high-school graduate. Many of the articles in the amendment are reminiscent of the original wordings, for example, 'to teach Israel's Torah, as well as its Jewish history, heritage, and traditions' (Amendment to the Israel National Education Act, 2000). However, along with these, there are articles that introduce a new spirit and new goals, for example, 'to become familiar with the language, culture, history, heritage, and unique traditions of the Arab population and of other population groups in the State of Israel' (this article also introduces into the legislature the 1976 goals for national Arab education). Thus, it would appear that this document resonates with the values characteristic of multicultural approaches. Alternatively, it is similar to what the European educational discourse refers as an intercultural approach (Dervin, 2015; Todd, 2011).

Through an interpretational analysis of major curriculum, the present study seeks to determine whether the current educational policy reflects the adoption of multicultural values that could potentially help strengthen weakened and marginalised population groups, or whether it successfully produces a multicultural rhetoric while engaging in ethnocentric curricula.

4 'Mizrachi' or 'Sephardic' is the term used to refer to the Jews who came from Islamic countries in Asia or northern Africa. 
The discussion focuses on the value education curriculum, which serves as the arena in which the State's preferred social values are delineated.

\section{Literature review}

\section{The melting pot policy}

The melting pot was the formal social and educational policy, which was dominant in the State of Israel during the first decades after it was founded. Of course, it is not an original Israeli policy. The term was first used in a play named 'Melting Pot', written by the British author and playwright Israel Zangwill. Debuting in 1908, the play presented an approach asserts that immigrants should assimilate "into a generalized "American" identity while shedding their indigenous cultural identities in the process' (Gaynor, 2011, p. 178).

The goal of that policy in Israel was to hide the visibility of the immigrants; the result of this official disregard of the immigrants' culture was the formation of a negative visibility (Resnik, 2010). This policy aimed 'to cut the new immigrants off from [...] their old traditions and to create in Israel a new uniform Hebrew-Israeli culture' (Zameret, 2002, p. 125), which in effect was a variation of the established Ashkenazi elite culture. More specifically, the melting-pot policy mainly fostered the identity of the national, secular Ashkenazi as representing the Israeli ethos.

The educational-ideological policy implemented in the state education systems was based (and still is) on the acculturation model of pedagogy, which advocates the transfer of values and subject matter in the teaching process (Lamm, 2001), for the purpose of leading a movement of social assimilation, based on clear guidelines.

Expression of the melting pot policy in the educational field can be found in the words of the third Minister of Education, Ben-Zion Dinur. While speaking about the history curriculum, he demanded that 'everything taught in school must assist in imparting to the student[s] these values, train [students] to absorb them... and promote the [values] as a guiding factor in forming [their] identity, thoughts and way of life. Nothing in the curriculum or school life should be opposed to these goals' (Kizel, 2005, p. 3).

Another example of the assimilation policy can be found through an in-depth examination of the curricula in all four separate sectors of the Israeli pre-academic education system. Article A of The Israel National Education Act of 1953 led to a reality in which the Israeli pre-academic education system was composed of four separate sectors: state-funded secular Jewish education; 
state-funded Jewish religious education; semi-independent Jewish ultra-Orthodox education; and state-funded education in Arabic. Perusal of the curricula of these separate sectors reveals that, in fact, religious Jewish education has roots in all of them. In the state-funded religious and in the ultra-Orthodox education systems, religion is taught within a religious framework and from a religious perspective. In contrast, in the state-funded secular Jewish education system teaching about religion serves an ethnocentric nationalist ideology. Originally, the legislation of 1953 was intended to end a heated debate in Israeli society between the secular and religious sectors. It was intended (at least allegedly) that the secular schools would feature a curriculum with a humanistic orientation that expresses a pluralistic worldview. However, that did not happen; thus, religious teachers are allowed to teach in the secular Jewish education sector, whereas secular teachers are denied the same privilege in the Jewish religious education sector.

The situation of the fourth sector, the separate but state-funded and dependent Arabic education sector, is even more complex. There is a mandatory curriculum for teaching about Jewish religion, culture, and history, in addition to a more marginal curriculum that teaches Islamic religion (Reingold, Baratz, \& Abuatzira, 2013).

\section{Pluralism via Integration}

The eventual replacement of the melting pot policy with the 'integration' or the 'cultural pluralism' policy at the end of the 1960 s did little to resolve these complexities. While the pluralist policy accepted the existence of various cultural groups within one political or social entity and even viewed it as normal (Lamme, 1996), its aim was 'to strive [...] for cultural integration of different groups that may become realized precisely because of the recognition of their right to exist' (ibid., p. 212). In other words, the pluralistic ethnocentric version of the new educational policy was reflecting a conception that advocated implicit assimilation. Underlying this approach was the view that particular and inferior cultures of minority groups should eventually disappear. The goal was identical to that of explicit assimilation, as it insisted that cultural and ethnic difference be assimilated into the traditions and customs of the majority. Recognition of the right of ethnic groups and communities to preserve their separate cultures was a policy of last resort. It was a policy of hypocrisy, which offered false recognition.

Indeed, in the period dominated by a formal pluralistic policy, the Ministry of Education director, Elad Peled, noted (in a policy paper regarding the 
principles for the educational system in the 1980s) the following: 'essentially, the Israeli culture that is taking form is nurtured, for the most part, by its shared past history' (Peled, 1976, p. 206). In other words, the orientation of the ethnocentric melting pot had not been eliminated.

In regards to the Arab education system, even during the policy of pluralism, this sector was subject to a discriminatory separatism, i.e. exclusion, in addition to being under the control and supervision of the state (Jabareen \& Agbarieh, 2010).

Unlike the Jewish ethnic groups that were brought together in middle school through the integration reform, the Arab education system remained separate. Exclusion, as well as control, were maintained. Reality was not changed, even though in 1975 a committee established by the Ministry of Education and headed by its manager (the Peled Committee) published a set of unique goals for the Arab education system, which up until that point had been subject to the ethnocentric Zionist goals defined in the National Education Law of 1953.

The committee offered the following goal for the Arab educational sector: 'to establish education based on the fundamentals of Arab culture; scientific achievements; the striving for peace between Israel and its neighbours; the love shared by all citizens for the Land of Israel; loyalty to the State of Israel, with emphasis on common interests and the unique position of Arab citizens in Israel; knowledge of Israeli culture; respect for creative work and the aspiration to create a society based on freedom, equality, mutual assistance, and love of humanity' (Ministry of Education, 1975, p. 14). However, this recommendation was not accompanied by any significant change in the legislature or by the granting of autonomy to the Arab education system. Textbooks, for the most part, were translated from Hebrew, and the Department for Arab Education and Culture within the ministry sought to decentralise Arab education and attach it to the existing regional administrative divisions of the Ministry of Education (Reichel, 2008).

Studies that have examined the history curriculum in Arab schools revealed that both in the past and in the present, Arab students have been, and continue to be, required to devote a major part of their studies to chapters in the history of the Jewish people, taught from a Jewish/Zionist perspective. In contrast, only the Arab educational sector is required to study Arab and Muslim history (and in a relatively limited form), whereas these subjects are absent from the curricula of the Jewish educational systems (Al-Haj, 1995, 2002; Shemesh, 2009). In other words, there is an infringement on the rights of Arab students to study the history of their people from the perspective of their 
people. This is due to the banning of any mention of the Nak'ba (the Palestinian term for events of the 1948 Israel War of Independence). Thus, in addition to the marginalisation of the study of Arab history and literature as well as the study of Islam (Pinson, 2005), students in the Arab educational sector are also required to study not only Jewish history, but also Jewish literature, and even the Jewish religion. In other words, the ethnocentric approach continued to dominate, even under the title of cultural pluralism.

The approach of ethnocentric pluralism that is implemented in Israel as described above has two main variations: the 'temporary pluralism' approach, which aims for the adoption of the dominant culture by the entire society, albeit through a gradual process. The second version is that of "residual multiculturalism, i.e. an approach that accepts the permanent preservation of marginal cultural dimensions within the minority groups (Sever, 2001).

\section{Multiculturalism}

Even though pluralism can serve ethnocentric approaches, it may also serve as a basis for multicultural perceptions. The pluralist multicultural ideology does not require communities to renounce their own unique cultures, but strives to sustain a dialogue on the cultural boundaries between members of different cultural groups that preserve their particular cultures (out of recognition of and pride in these cultures), without creating a cultural hierarchy or attempting cultural colonialism (Reingold, 2009).

There are different multicultural approaches, and there is much debate among the advocates of multiculturalism (Gorski, 2009; Paul-Binyamin \& Reingold, 2014).

Nevertheless, there is a consensus that multicultural ideology (or intercultural ideology), which in Israel goes back only a few decades, aims to advance a policy that encourages a relationship of mutual respect among the various cultures that comprise a society (Paul-Binyamin \& Reingold, 2014; Reingold, 2007).

It is a 'policy of maintaining a diversity of ethnic cultures within a community', and it upholds 'the view that the various cultures in a society merit equal respect and scholarly interest' (Raţă, 2013, p. 3). In other words, it is 'a philosophy that appreciates ethnic diversity within a society and that encourages people to learn from the contributions of those with diverse ethnic backgrounds' (ibid.).

All of these definitions and characteristics are to be distinguished from what Peter McLaren (1995) defines as 'conservative multiculturalism', or what 
I prefer to regard as 'feigned multiculturalism' (Baratz, Reingold, \& Abuatzira, 2011), meaning a rhetoric which uses the terms multiculturalism and diversity to cover up a practice of assimilation.

True multiculturalism claims that cultural diversity and intercultural dialogue are necessary elements of culturally diverse societies; hence, educational manifestations of this ideology may involve the construction of common educational public spaces shared by members of different cultural communities. At an earlier stage of the multicultural process, educational implementation of this ideology may require maintaining separate public educational spaces for different cultural minorities. This is to empower the community members of each group and to prepare them for an intercultural dialogue from a position of strength, that is, defining an early stage of a particular form of multiculturalism (Reingold, 2007).

Banks (1995) identified five dimensions of multicultural education: content integration, the knowledge construction process, prejudice reduction, an equity pedagogy, and an empowering school culture and social structure. Teachers can add to the curriculum examples and content from a variety of cultures. They can help students to understand how the biases are being constructed. They can help students to develop positive attitudes toward different racial, ethnic, and cultural groups; modify their teaching in ways that will facilitate the academic achievement of students from diverse groups and transform the culture and organisation of the school in ways that enable students from diverse groups to experience equality.

Multicultural curricula can help counter separatist and racist social phenomena, such as the pervasiveness of an exclusionary national mythology. Multicultural curricula can achieve this by rehabilitating the self- and social-image of the other, and by giving voice to the cultural narratives of oppressed groups. The struggle of minority groups for recognition is based on the assumption that representation equals power: 'I am in the text; therefore, I am'.

The current study analyses a text: the syllabi of contemporary Israeli value education program, titled: 'The other is myself'.

For several decades, the Ministry of Education in Israel chooses a values-based topic to be addressed for one academic year in elementary, junior high, and high schools. A modest number of classroom hours is allotted to values-based education, during which the lesson is dedicated to the selected topic. The topic is applied to major theoretical disciplines, such as history and Bible studies, as well as to other disciplines, such as music and dance.

In 2009, the values-based education was expanded to a core curriculum program, in which, the same values-based education approach and the same 
values-based topic will be the centre of the educational activities, both in some major theoretical disciplines' lessons and throughout the year in one weekly lesson carried out by the homeroom teacher. The guiding principles are the same in all the syllabi of the values-based educational core curriculum program, but each educational institution can choose its own particular manner of implementation (Ministry of Education, 2015).

The topic selected beginning at the 2013-2014 school year was 'The other is myself'; by the 2015-2016 academic year the Ministry of Education published a folder of educational activities and suggested statement to be signed by teachers and pupils at schools concerning the subject. (The other is myself, The Ministry of Education, 2015). The program comprised 142 syllabi meant to address the multicultural approach.

According to the Ministry of Education's (2014) document 'Mutual life', living in a multicultural society is a significant challenge in the State of Israel. Due to partisan disputes, Israeli society often becomes fertile ground for feelings of fear, ignorance and prejudice. Therefore, the Israeli education system has no choice but to be a leading factor in constructing moral education commitment and to change the mistrust and hatred between the various groups in the Israeli society to partnership and mutual respect.

Thus, the program aims at presenting multicultural approach based upon universal-humanistic values, as can be perceived in the following excerpt:

This step prioritizes universal values of respect, equality, justice, tolerance, acceptance and passion, democracy, identity, and belonging [...] [conveying an] understanding that there is difference in each of us, and it introduces the advantage of variability in terms of thinking, learning, conducting society [...] [The program aims to] reject the phenomenon of racism and purge Israeli society of all forms of racism.

Hence, the current research aim was to analyse the educational program 'The other is myself' to determine whether it reflects the adoption of multicultural values that could potentially help strengthen weakened and marginalised population groups, or whether it produces a multicultural rhetoric while engaging in ethnocentric curricula.

The research question was as follows:

Are the declared goals compatible with the issues and topics addressed in the program? In other words, are the issues and topics addressed in the program compatible with the stated multicultural educational policy in Israel? 


\section{Methodology}

In accordance with the research aim, namely, to determine whether the program reflects the adoption of multicultural values, a qualitative-interpretive research method was applied to analyse the documents at hand. A textual analysis was performed according to the principle of critical discourse that focuses on social problems and the various forms of language used in regard to underprivileged minority groups that are discriminated on the grounds of ethnicity or social status (Gee, 1992; 2004). The analysis was also based on Klein's method (Klein, 2010, following van Dijk, 1991), which is intended for analysing sociocultural connections and the implicit meanings derived from them.

In detail, following Banks' five dimensions of multicultural education, we were determining whether the contents represent underprivileged minority groups' cultures or the references towards those groups are patronising, ethnocentric, or multicultural.

For example, even before the deep analysis, we could reveal that the authors of the program chose not to use the word different but rather the word other, which appears also in the name of the program. The term different conveys the idea that all human beings are equal, but have distinct features and characteristics, whereas the term other refers to 'any being that is not me, that isn't like me in terms of values, abilities, or worldview' (Abu-Baker, 2002, p. 32).

In comparison to other tools of measurement, content analysis has major advantages. A series of procedures is used in analysing the text aimed at arriving at significant diagnoses and generalisations from within the text (Weber, 1990). According to Scholes' (1985) assumption, content analysis involves reading within, on, and against the text. Reading within the text means understanding the text according to its author's intention; reading on the text means interpreting it according to the reader's understanding; reading against the text means criticism, support or objection, and fathoming the reader's arguments, according to his understanding, which is based on his previous knowledge and cultural background.

It is not invasive; it is free of errors in data analysis stemming from the respondents' awareness of the examiner's presence and expectations, and it is also a technique that is able to deal with a large amount of data such as data retained from curricula (Krippendorff, 2004).

The corpus: The program 'the other is myself'. For the three main educational systems in Israel: secular Jewish education, religious Jewish education, and Arabic education within the entire ELHI education (elementary to high school education). 
The program is composed of 142 different syllabi for the following disciplines: Language Hebrew, Arabic \& English, Yiddish), literature, Bible, and Oral Torah.

History, Sociology, Psychology, Homeland studies, Social science, Political science, Economics, Citizenship, Health education, Legacy studies, Communication, Dancing, Music, Theatre, Gymnastics and Arts.

The following rubric was used in order to determine the effectiveness of the program according to the research questions:

Ethnocentric rhetoric - Conveying the belief that one's own culture is superior to all others and is the standard by which all other cultures should be measured. Demonstrating a model of social integration or cultural assimilation. In the current study, it means that the Jewish Zionist culture has been regarded as the superior one.

Pluralistic rhetoric - Allowing deepest cultural differences. Exercising tolerance or benevolent paternalism.

Multicultural rhetoric - Promoting ideas of dialogue and promotion of multiple cultural traditions within a single jurisdiction. Maintaining the distinctiveness of multiple cultures in contrast to social integration, cultural assimilation and racial segregation.

Irrelevant or unrelated rhetoric - None of the above.

The reliability of the current research was calculated according the method of percentage agreement among researchers. Since only four cases of disagreement (out of 142) occurred, the reliability percentage was 97\%. This high percentage was despite the fact that the researchers in the field of education come from different areas: one researcher's fields of expertise is multicultural education and philosophy of education, while the others are experts in sociology of education and educational management.

\section{Findings}

We found that the categories: ethnocentricity, multiculturalism and pluralism in some cases were not purely distinctive within the syllabi layout of the program 'The other is myself'; hence, two intermediate categories were also elicited: Ethnocentrism + Pluralism (10 cases) as well as Pluralism + Multiculturalism (8 cases). Those inconclusive categories reflect the in-between situation between the original categories, offered by the rubric.

The number of appearances in the syllabi according to the categories:

Ethnocentrism 12

Ethnocentrism+ Pluralism 10 
Pluralism

Pluralism + Multiculturalism 8

Multiculturalism 22

Unrelated/Irrelevant $\quad 31$

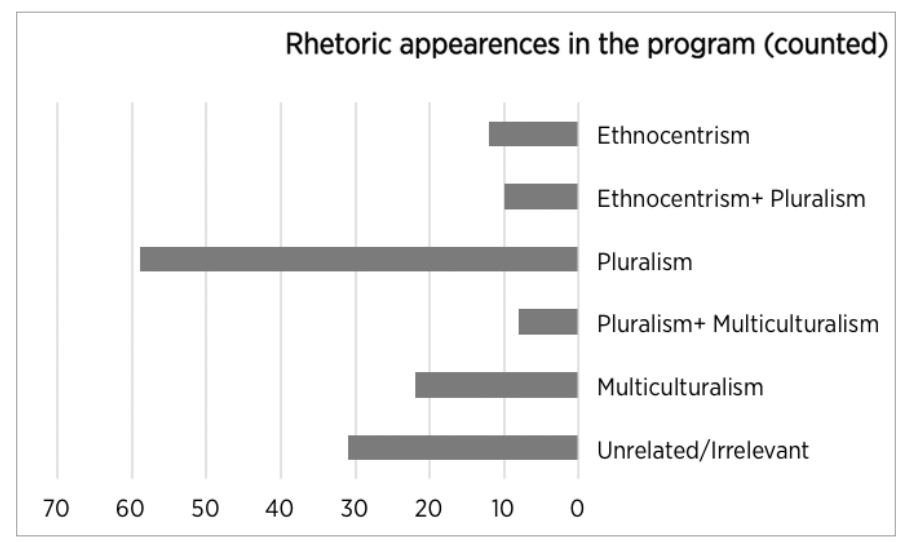

Figure 1. Rhetoric appearances in the program (counted)

Within the entire of the program, 31 syllabi were defined Unrelated or Irrelevant to the categories defining the rhetoric above.

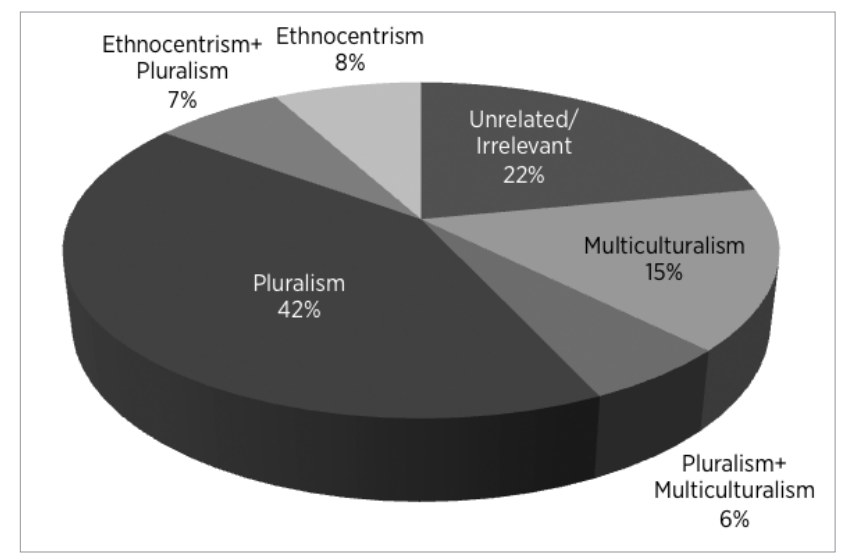

Figure 2. Rhetoric appearances in the program (percentages)

Thus, the pluralistic rhetoric represents the vast majority of the syllabi in the program. 
Table 1

The distribution of the rhetoric appearances and their representative statements

\begin{tabular}{|c|c|c|c|}
\hline Rhetoric/style & $\begin{array}{c}\text { No. of } \\
\text { appearances }\end{array}$ & Percentages & Representative syllabi \\
\hline Ethnocentrism & 12 & $8 \%$ & $\begin{array}{l}\text { 1-History for the state religious sector (Junior } \\
\text { high school): 'Jewish aid institutes in the Jewish } \\
\text { community during the Middle Ages - benevolence, } \\
\text { charity and grace'. } \\
\text { 2-Oral Torah (Bible) for the state general sector } \\
\text { (Junior high school): 'Studying the scriptures of } \\
\text { Sages from the Mishna and the Talmud-Between } \\
\text { the genders -various aspects of marriage'. }\end{array}$ \\
\hline $\begin{array}{l}\text { Ethnocentrism+ } \\
\text { Pluralism }\end{array}$ & 10 & $7 \%$ & $\begin{array}{l}\text { 1-Health Education for all sectors (Junior high } \\
\text { school): 'Celebrating Bar Mitzvah - wise nutrition } \\
\text { of Israel's various ethnic groups'. } \\
\text { 2-Arabic for the Druze and Cherkasy sectors } \\
\text { (elementary school): Acceptance, inclusion and } \\
\text { caring about the language, the community and the } \\
\text { homeland'. }\end{array}$ \\
\hline Pluralism & 59 & $42 \%$ & $\begin{array}{l}\text { 1-Gymnastics for all sectors (elementary school): } \\
\text { 'Inclusion and empathy towards the different } \\
\text { other'. } \\
\text { 2-Theatre studies for all sectors (high school): } \\
\text { 'Empathy for the other through playing his/ her } \\
\text { character in a play'. }\end{array}$ \\
\hline $\begin{array}{l}\text { Pluralism+ } \\
\text { Multiculturalism }\end{array}$ & 8 & $6 \%$ & $\begin{array}{l}\text { 1-History for all sectors (Junior high school): 'De- } \\
\text { veloping tolerance towards Christianity, Judaism } \\
\text { and Islam-knowing and respecting each other'. } \\
\text { 2-Film studies for all sectors (Junior high school): } \\
\text { 'The representation of the other in films - Knowing, } \\
\text { understanding and accepting the other }\end{array}$ \\
\hline Multiculturalism & 22 & $15 \%$ & $\begin{array}{l}\text { 1-Legacy studies for all sectors (Junior high } \\
\text { school): 'Preventing violence and racism'. } \\
\text { 2-History for the state general sector (high } \\
\text { school): 'Immigration absorption in Israel during } \\
\text { the 1950s and '60s and the riots of 'Wadi Salib'. }\end{array}$ \\
\hline $\begin{array}{l}\text { Unrelated/ } \\
\text { Irrelevant }\end{array}$ & 31 & $22 \%$ & $\begin{array}{l}\text { 1-Music for all sectors (elementary school): No } \\
\text { specific aims. } \\
\text { 2-Bible studies for the state religious sector } \\
\text { (high school): 'Different aspects of child- parent } \\
\text { relationships'. }\end{array}$ \\
\hline
\end{tabular}

\section{Discussion}

With its founding, the State of Israel declared a social and educational approach of overt assimilation. The purpose of this policy was to ensure that the Ashkenazi Zionist culture would be the predominant culture in Israel; in other words, it would be conceived as the only true Israeli culture. Several decades later, this policy was replaced by another, which claimed to manifest an approach of cultural pluralism. However, in fact, it merely replaced the overt 
assimilation policy with a covert one (occasionally during this period, the goal of assimilation was declared openly).

In the last decade and a half, the Ministry of Education has been producing a multicultural rhetoric, both in its general policy statement and in its curricular documents.

Analysing the rationale and the syllabi of the contemporary Israeli value education program, ('The other is myself'), we identified a mixture of terminologies from the ethnocentric, pluralistic and multicultural approaches. The contradiction between the three approaches is profound; while pluralism allows the deepest cultural differences; Multiculturalism promotes ideas of respect and inter cultural dialogue resulting in the promotion of multiple cultural traditions within a single jurisdiction without exercising benevolent paternalism. Ethnocentrism, in contrast, exercises social integration or cultural assimilation of multiple cultural groups.

Purely ethnocentric rhetoric appeared 12 times within the program. Its use of a gentler rhetoric, which supposedly embraces multiculturalism, may actually prevent the realization of multiculturalism. Those syllabi use terms that are not derived from a multicultural approach, such as 'the ethnic group of Mizrachi (Oriental) Jews' (in Hebrew: edot hamizracc), which is the exclusionary term, rather than 'the community of descendants of immigrants from Muslim countries' which is the term used in multicultural discourse.

The religious Jewish education system, in contrast, features no such syllabi for presenting non-Jewish cultures. At most, its equivalent programs focus on the issue of tolerance in Judaism, e.g. historical examples of renowned acts of piety; Jewish laws regarding charity for those in need in society; showing respect for older people; etc. In classes in Yiddish in religious schools, the socalled 'other' that students learn about is the oppressed Jews of Eastern Europe (e.g. the Beilis Trial). It remains unclear precisely how Jews represent the 'other' for Jewish students. Religious schools also deal with topics such as parents and children, converts to Judaism, the other in the Bible, love and relationships, organ donation, the treatment of older people throughout history, proper nutrition among the various ethnic groups, sustainability and cycles in nature, and the dangers of smoking. All of these are issues of great importance, yet they have no concrete connection to multiculturalism (occasionally they are not even related to variability or otherness), although their study is accompanied by extensive use of the terms mutual responsibility, care and concern, and tolerance.

However, the vast majority of the syllabi in the program (59) reflect the pluralistic approach, sometimes combined with the ethnocentric approach (10); despite their use of a multicultural heading, it is evident that no multicultural 
approach has yet been internalized in those syllabi.

The use of the phrase 'other' instead of 'different' characterizes an ethnocentric approach for it emphasizes the 'self'. The use of further problematic phrases (from the multicultural perspective), such as 'tolerance' for the other and the different may convey a patronizing approach. It suggests that I am the one in power and, therefore, it is up to me to tolerate and be receptive towards the other. The proper expression in a multicultural context would be 'learning about differences', rather than the notion of forced acceptance. The patronizing undertone is also perceived in an additional term that appears in the program's rationale: 'taking care of those in society who are weaker'. A multicultural wording would use disadvantaged rather than weakened, and taking care of others should be replaced by helping to empower others.

The major problem in this program becomes obvious when we examine its goals. Even though the program aims at multiculturalism, only 22 syllabi (15\%) convey specific multicultural contents to be applied in the various disciplines and in the different education systems.

In some cases (8), one can trace a mixture of multicultural and pluralistic rhetoric. For example, the versions of the program that include a dialogue component, titled Archeology in the Land of Israel, includes both online and face-toface meetings between students from different education systems. However, the goal of the syllabi is worded in pluralistic (rather than multicultural) terms: it aims to develop in students 'a tolerant approach and respect for ethnic cultures and [minority] religions in Israel'. The second version of the program that offers a true dialogue experience is titled 'getting to know the other and preventing racism' and it should include 'encounters between students from either the Jewish and the Arab education systems or the secular and religious Jewish education systems, for the purpose of conducting a joint research project'.

The only elementary school versions of the program that contain a certain degree of dialogue are titled 'Let's Talk' and 'Ya Salam', which are taught in the framework of Arabic language lessons for the Jewish sector. This program includes dialogue and activities that take place between Jews and Arabs; however, these encounters are not real, but rather described in the textbook. Nevertheless, the goals of the program are defined in a manner that reflects a multicultural approach: their goal is to: 'develop a sensitivity towards people from different cultural backgrounds. Learning Arabic gives students the opportunity to learn about the rich cultural heritage of the Arab and Muslim people and their traditions'.

There is however, a small number of programs intended for the statefunded religious schools for learning about the cultural heritage of Arabs and 
Muslims and their traditions: 14 for elementary schools, one for junior-high schools and one for high schools. These do not include actual meetings with members of Arab communities.

In contrast to the two Jewish state sectors, the Arab education system includes not only mandatory studies about the Jews, their culture, and their history, but also the teaching of the values-based program focuses on the Jews. For example, in the program for elementary schools, they learn about King Solomon and social justice, or about the Ten Commandments (for some unknown reason, both are taught in the framework of history lessons).

In other words, the value education program dedicated to learning about the other or about differences (which is relatively limited in scope, occasionally comprising only five academic hours) is at best pluralistic (rather than multicultural) in its use of terminology, as is much of its content, which in more than a few cases is even ethnocentric. Only a very small number of programs feature intercultural dialogue, while few focus on issues relating to the struggle against or prevention of racism. In the $21^{\text {st }}$ century, diversity is one of the main characteristics of all the countries in the world. Cultural groups live side by side. In all the countries, one of the variables of cultural diversity relates to religious beliefs and/or affiliations (including being secular). In many countries, several national groups side by side. Either indigenous or immigrants. In many of the most attractive countries for immigrants, such as Australia, Western Europe or North American countries, politicians and educational policy makers are promoting for several decades multicultural/intercultural education policy and curricula (Todd, 2011). Some more efforts and action will be probably taken after the summer 2015 wave of migration from the Mideast to Europe. The current paper urges education researchers not to be misled by multicultural or intercultural rhetoric, but rather to deeply analyse the educational curricula and programs. Although the topic may appear to encompass a multicultural approach, a review of the wording used to describe the topic and its goals reveals that this is not the case.

The current paper focuses on a national educational policy. Nevertheless, its significance to the international educational discourse is the exposure of a gap between manifestoes of educational policy and a practical educational policy. Text analysis of value education curricula reveals that a change in a rhetoric of an educational policy is not always followed by a real change in educational ideology. 


\section{References}

Abu-Baker, H. (2002). אחד עשרה נקודות על אחרות, שוויון ורב תרבותיות[Eleven comments about otherness, equality and multiculturalism]. פנים [Panim], 22, 32-38.

Al-Haj, M. (1995). Education, empowerment and control: The case of the Arabs in Israel. Albany, NY: State University of New York Press.

Al-Haj, M. (2002). The history curriculum in Jewish schools and in Arab schools in Israel: Ethnocentrism versus controlled multiculturalism. In A. Ben-Amos (Ed.), היסטוריה, זיכרון וזהות: דימויי [History, identity and memory: Images of the past in Israeli education] (pp. 137-154). Tel Aviv: Ramot.

חוק חינוך ממלכתי [Amendment to the Israel national education act of 1953] (2000).

Baratz, L., \& Reingold, R. (2010). The ideological dilemma in teaching literature process - moral conflicts in a democratic and nationally diverse society: An Israeli teacher case study. Current Issues in Education 13(3), 1-27. Retrieved from 883/weiv/elcitra/usataeic/php.xedni/sjo/ude.usa.eic//:ptth

Baratz, L. Reingold. R., \& Abuatzira, H. (2011). Bi-lingual newspaper as an expression of a Fake multicultural educational policy in Israel. International Education Studies, 4(4), 160-167. Retrieved from http://www.ccsenet.org/journal/index.php/ies/article/view/12889/9043

Banks, J. A. (1995). Multicultural education: Historical development, dimensions, and practice. In J. A. Banks \& C. A. M. Banks (Eds.), Handbook of research on multicultural education (pp. 3-24). New York, NY: Macmillan.

Dervin, F. (2015). Towards post-intercultural teacher education: Analysing 'extreme" intercultural dialogue to reconstruct interculturality. European Journal of Teacher Education, 38(1), 71-86.

Feinberg, W. (1996). The goals of multicultural education: A critical re-evaluation. In F. Margonis (Ed.), Philosophy of education (pp. 182-189). Urbana, IL: Philosophy of Education Society.

Gaynor, A. R. (2011). Beyond the melting pot finding a voice for Jewish identity in multicultural American schools. Journal of Jewish Communal Service, 86(1-2), 174-183.

Gee, J. P. (1992). The social mind: Language, ideology, and social practice. New York, NY: Bergin and Garvey.

Gee, J. P. (2004). Situated language and learning: A critique of traditional schooling. London, UK: Routledge.

Gorski, P. C. (2009). What we're teaching teachers: An analysis of multicultural teacher education coursework syllabi. Teaching and Teacher Education, 25(2), 309-318.

Gur-Ze’ev, I. (1999). פילוסופיה, פוליטיקה וחינוך בישראל [Philosophy, politics and education in Israel]. Haifa: University of Haifa press.

חוק חינוך ממלכתי [Israel national education act] (1953).

Jabareen A., \& Agbarieh A. (2010). חינוך בהמתנה: מדיניות הממשלה ויוזמות אזרחיות לקידום החינוך הערבי [Education stalled: Governmental policy and civic initiatives for advancing Arab education in Israel - A status report]. Nazareth, Dirasat, and Haifa: Haifa University, The Clinic for the Rights of the Arab Minority. 
Kizel, A. (2005). Europe-centrism in Israel's general history textbooks (1948-2004). Essays in Education, 15. Retrieved from http://www.usca.edu/essays/vol152005/kizelrev.pdf

Klein, A. (2010). Analysis of critical discourse of newspapers. In L. Kasan \& M. Krumer-Nevo (Ed.), Qualitative investigation data analysis (pp. 230-254). Be'er Sheva: Ben-Gurion University.

Krippendorff, K. (2004). Content analysis: An introduction to its methodology (2nd ed.). Thousand Oaks, CA: Sage

Lamme, Z. (1996). רעיון הפלורליזם ויישומו בחינוך הישראלי [The idea of pluralism and its implementation in Israeli education]. In I. Gur-Zeev (Ed.), חינוך בעידן השיח הפוסטמודרניסטי [Education in the era of postmodernist discourse] (pp. 207-220). Jerusalem: Magnes Publishers.

Lamm, T. (2001). ערכים וחינוך [Values and education]. In Y. Iram, S. Shkolnikove, \& E. Shekter (Eds.), [Crossroads: Values and education in Israeli society] (pp. 651-664). Jerusalem: Ministry of Education Press.

McLaren, P. L. (1995). White terror and oppositional agency: Towards a critical multiculturalism. In C. E. Sleeter \& P. L. McLaren (Eds.), Multicultural education, critical pedagogy, and the politic of difference (pp. 30-70). New-York, NY: State University of New York Press.

Ministry of education and culture (1975). דוח צוות החינוך הערבי, פרויקט תכנון החינוך לשנות ה- 08 [A report of the Arab education staff. Jerusalem: Project for education planning for the 1980s]. Jerusalem: Ministry of education and culture.

Ministry of education, Israel curriculum center (2010). תכנית הלימודים החדשה בהיסטוריה [The new curriculum in history for Jewish state religious education]. Jerusalem: Ministry of education.

"“האחר הוא אני“-תכנית הלימודים החדשה בחינוך לערכים.(2013) Ministry of education, Israel curriculum center ['The other is myself'- A new curriculum in education for values]. Jerusalem: Ministry of education. Ministry of education (2015). תפיסה חינוכית ערכית מגן עד י"ב [Values-based education approach from kindergarten to grade 12]. Retrieved from http://meyda.education.gov.il/files/noar/acherani2015.pdf [Mutual life], Jerusalem: The ministry of education (2014). Retrieved from http://cms. education.gov.il/EducationCMS/Units/ui/gizanut/chatab/HaimMesutfeim.htm

Paul-Binyamin I., \& Reingold, R. (4102). Multiculturalism in teacher education institutes - The relationship between formulated official policies and grassroots initiatives. Teaching and Teacher Education, 42, 47-57.

Peled, A. (1976). Education in Israel in the 1980s. Jerusalem: Ministry of education and culture. Pinson, H. (2005). Between a Jewish state and democracy: Tensions and contradictions in the curriculum for civic studies. Politics, 14, 9-24.

Rață, G. (2013). Cross-cultural, cross culturally, cross-cultural. In H. Arslan \& G. Rata (Eds.), Multicultural education: from theory to practice (pp. 3-14). Newcastle upon Tyne, UK: Cambridge Scholars Publishing.

Reichel, N. (2008). The story of the Israeli education system - centralized or decentralized? Overt or covert? Imitation or original? Jerusalem: Mofet Institute and Magnes.

Reingold, R. (2007). Promoting a true pluralistic dialogue - a particularistic multicultural teacher accreditation program for Israeli Bedouins. International Journal of Multicultural Education, 9(1), 1-14. 
Retrieved from http://journals.sfu.ca/ijme/index.php/ijme/article/view/6

Reingold, R. (2009). אידיאולוגיה רב-תרבותית: מונחים, פולמוסים והשתמעויות חינוכיות [Multicultural ideology: terms, polemics, and educational meanings]. Massad, 7, 6-13.

Reingold, R., Baratz, L., \& Abuatzira, C. (2013). Conformity and compliance as moral acts: The case of teachers in Jewish religious state schools in Israel. The International Journal of Education for Diversities, 2, 461-1.

Resnick, G. (2010). נראות וזהות בבתי ספר רב-תרבותיים בישראל [Visibility and identity in multicultural schools in Israel]. In A. Lomsky-Feder \& T. Rappaport (Eds.), נראות בהגירה: גוף, מבט, ייצוג [Visibility at immigration - body, view, representation] (pp. 274-302). Jerusalem: Van Leer Jerusalem Institute and Ha-Kibbutz Ha-Meuchad.

Scholes, R. E. (1985). Textual power: Literary theory and the teaching of English. New Haven, CT: Yale University Press.

Sever, R. (2001). בוללים או שוזרים? מסגרת מושגית לבחינת סוגיות של רב תרבותיות [Mix or interlace? The conceptual framework for analysis of issues of multiculturalism]. Gadish, 7, 45-54.

Shemesh, H. (2009). עיצוב הזיכרון בספרי לימוד בהיסטוריה לבתי הספר הערביים במדינת ישראל 84918002 [Fashioning memory through history textbooks in Arabic in Israel (1948-200o)] Unpublished doctoral dissertation. The Hebrew University, Jerusalem.

[The other is myself], Jerusalem: The ministry of education (2014). Retrieved from http:// cms.education.gov.il/EducationCMS/Units/ui/atochnit/ogdan/Ratzyonal.htm

[The other is myself], Jerusalem: The ministry of education (2015). Retrieved from http:// cms.education.gov.il/EducationCMS/Units/ui/

Todd, S. (2011). Educating beyond cultural diversity: Redrawing the boundaries of a democratic plurality. Studies in Philosophy and Education, 3o(2), 101-111.

Van Dijk, T.A. (1991). Racism and the press. London, UK: Rutledge.

Weber, R. P. (1990). Basic content analysis. Beverly Hills, CA: Sage

Yonah, Y. (2005). בזכות ההבדל - הפרוייקט הרב תרבותי בישראל [In virtue of difference: the multicultural project in Israel]. Jerusalem: The Van Leer Jerusalem Institute.

Zameret, Z. (2002). The melting pot in Israel: The commission of inquiry concerning the education of immigrant children during the early years of the state. New York, NY: SUNY Press. 


\section{Biographical note}

Roni Reingold, $\mathrm{PhD}$, is the chair of Master of Teaching program in Achva Academic College. He is the previous chair of department of Education. He is the organizer and the chair of the EARLI's 2nd SIG 13-Moral and Democratic Education symposium (2010). He published articles in the fields of multicultural education, moral education and initial teacher education.

SARA ZAMir, PhD, is a senior lecturer at Achva Academic College and Ben-Gurion University. She serves as the Head of the B.Ed - Educational Administration program at Achva academic college. She published articles and books in the fields of peace-education, political socialization and educational evaluation. 